\section{4-Nonylphenol disrupts osmoregulation in the \\ European sea-bass Dicentrarchus labrax}

\author{
C. Lorin-Nebel, ${ }^{1}$ H. Budzinski, ${ }^{2}$ \\ K. Le Ménach, ${ }^{2}$ M.H. Devier, ${ }^{2}$ \\ G. Charmantier, ${ }^{1}$ R. Gros, ${ }^{1}$ E. Grousset, ${ }^{1}$ \\ E. Blondeau-Bidet, ${ }^{1}$ E. Farcy ${ }^{1}$
}

'Université Montpellier 2, Equipe AEO

Adaptation Ecophysiologique et

Ontogenèse, UMR 5119, Ecosym, UM2-

CNRS-IRD-Ifremer, Montpellier; ${ }^{2}$ CNRS, UMR 5805 EPOC, Université Bordeaux 1,

Talence, France

\section{Introduction}

4-Nonylphenol (4-NP) is a synthetic organic chemical able to mimick the action of the natural female hormone $17 \beta$-estradiol (E2) by binding to the E2 receptor. ${ }^{1} 4$-NP is a degradation product of nonylphenols polyethoxylates (NPEs), which are widely used as surfactants. ${ }^{2}$ It can be found in seawater at maximal concentrations of around one to four micrograms per liter. ${ }^{3}$ The most contaminated marine sites are estuaries, lagoons and coastal areas close to sewage treatment plants or industrial waste discharges. Reproductive disorders associated with 4-NP exposure have been well described in $\mathrm{fish}^{4,5}$ but less attention has been paid to other hormone-regulated functions such as osmoregulation. In the past decade, several studies highlighted that 4-NP may disrupt endocrine control of osmoregulation in salmonids, notably during the smoltification process. $^{6-9}$ To date, the endocrine disruption of osmoregulatory pathways has been poorly studied in teleosts other than salmonids.

The European sea-bass Dicentrarchus labrax is an euryhaline marine teleost commonly found along the coasts of the north-east Atlantic Ocean and the Mediterranean Sea. D. labrax migrates in lagoons and estuaries where salinity is generally lower and more variable than in the open sea and where the concentrations of anthropogenic pollutants such as 4-NP are supposed to be higher. The endocrine regulation of osmoregulation in $D$. labrax involves several hormones including pituitary hormones such as somatolactine (SL), prolactin (PRL) and growth hormone $(\mathrm{GH})^{10}$ as well as cortisol, a glucocorticoid released by inter-renal cells ${ }^{11}$ and the insulinlike growth factor I (IGF-I), predominantly released from liver cells. ${ }^{12}$ The GH/IGF-I axis is known to be involved in the seawater acclimation process of teleosts whereas prolactin pro- motes ion uptake in fresh water. ${ }^{12}$ Cortisol has been shown to interact with both of these hormones and is believed to have a dual osmoregulatory function. ${ }^{13}$ The goal of the present study was to investigate whether 4-NP disrupts hypo-osmoregulation and its hormonal control in D. labrax following aqueous exposure.

\section{Materials and Methods}

Juvenile sea-bass $(60.8 \pm 6.5 \mathrm{~g}$ and $19.0 \pm 1.2$ $\mathrm{cm}$, mean \pm SD) were obtained from the culture system at the IFREMER station at Palavas (Hérault, France). After their transfer to the laboratory in Montpellier, the fish were acclimatized in $3500 \mathrm{~L}$ tanks filled with aerated and filtered natural seawater. For the experiments, the fish were kept in $200 \mathrm{~L}$ glass aquaria (temperature: $19^{\circ} \mathrm{C}$; dissolved oxygen: $9 \mathrm{mg} / \mathrm{L}$; salinity: 37\%; pH 7.0-8.0; photoperiod: $12 \mathrm{~h}$ light/12 h dark). Fish were not fed during the experiments. Ten fish per aquarium were exposed during 6 days at a daily nominal concentration of $100 \mu \mathrm{g} / \mathrm{L}$ of 4-NP (CAS 84852-1513, Sigma-Aldrich Chemicals, MO, USA). 4-NP was dissolved in methanol, while the control group received the carrier solvent alone $(0.002 \%$ methanol). The exposure was performed under static conditions and half of the water was changed every $48 \mathrm{~h}$. Water was sampled $5 \mathrm{~min}, 4 \mathrm{~h}, 8 \mathrm{~h}, 12 \mathrm{~h}$ and $24 \mathrm{~h}$ following 4 NP addition and 4-NP measurements were carried out by SPME/GC/MS. 4-NP was removed from contaminated water with granular activated carbon as recommended. ${ }^{14}$ For sampling, animals were anesthetized with $200 \mathrm{ppm}$ of phenoxy-2-ethanol (Galaxy Surfactants Ltd., Mumbai, India). Blood was collected from the dorsal aorta using a $1 \mathrm{~mL}$ syringe coated with heparin (Li-heparin, Sigma-Aldrich, France) and blood osmolality was measured rapidly after collection using an Advanced 3300 microosmometer (Advanced Instruments Inc., MA, USA). Pituitary glands and gills were dissected on ice and immediately stored in Trizol reagent (Invitrogen, France) at $-80^{\circ} \mathrm{C}$ for molecular biology analyses. Animal manipulation and experiments were performed according to the recommendations of the European Union directive (2010/63/EU) and of the French law (decree 87/848) regulating animal experimentation.

Total RNA was extracted using Trizol reagent according to the manufacturer's instructions and $500 \mathrm{ng}$ of the total RNA was treated with RNase-free DNase (Invitrogen, France). Quantification of total RNA was performed with a NanoDrop® ND-1000 V3300 Spectrophotometer (Nanodrop Technology Inc., USA) and the RNA integrity was checked by electrophoresis. Reverse transcription was performed using M-MLV reverse transcriptase
Correspondence: Emilie Farcy, Université Montpellier 2, Equipe AEO Adaptation Ecophysiologique et Ontogenèse, UMR 5119, Ecosym, UM2-CNRS-IRD-Ifremer, Place Eugène Bataillon, CC 092, 34095 Montpellier Cedex 05, France.

E-mail: Emilie.Farcy@univ-montp2.fr

Key words: Dicentrarchus labrax, osmoregulation.

Conference presentation: ECOBIM meeting, 2014 May, Brest, France.

This work is licensed under a Creative Commons Attribution NonCommercial 3.0 License (CC BYNC 3.0).

(C) Copyright C. Lorin-Nebel et al., 2014

Licensee PAGEPress, Italy

Journal of Xenobiotics 2014; 4:4905

doi:10.4081/xeno.2014.4905

and random primers (Invitrogen, France). Quantitative real-time PCR (qRT-PCR) analyses were performed with a Light-Cycler system (Roche, Mannheim, Germany), using 2.5 $\mu \mathrm{L}$ of the LightCycler-FastStart DNA Master SYBRGreen Mix (Roche), $0.75 \mu \mathrm{L}$ of each primer (reverse and forward at $0.5 \mu \mathrm{M}$, Table 1) and $2 \mu \mathrm{L}$ of cDNA. The results were normalized with the ribosomal protein L13a, a housekeeping gene already validated in the seabass. $^{15}$

The data were expressed as the mean \pm standard deviation. Differences between control and groups of fish exposed to 4-NP were evaluated by t-test $(\mathrm{P} \leq 0.05)$. The calculations were performed using Statgraphics Centurion XV software (StatPoint, Inc., http://www.statgraphics.com/).

\section{Results and Discussion}

Alkylphenols such as 4-nonylphenol (4-NP) are one of the wide variety of environmental chemicals reported to have estrogenic effects, however little work has been done on their effect on osmoregulation in euryhaline teleosts, other than in salmonids. In the current study, a nominal concentration of $100 \mu \mathrm{g} / \mathrm{L}$ was used. Chemical analysis of water revealed that this nominal concentration corresponds to a mean 4-NP concentration of $40 \pm 20 \mu \mathrm{g} / \mathrm{L}$. This concentration corresponds to 10 times the highest concentrations recorded in marine environments $(4 \mu \mathrm{g} / \mathrm{L}$ along the northern Mediterranean coasts) ${ }^{3}$. At these concentrations, no mortality occurred during the treatment period. 4-NP exposure did not affect mean blood osmolalities compared to controls $(367 \pm 11 \mathrm{~m} 0 \mathrm{sm} / \mathrm{kg}$ vs $358 \pm 9 \mathrm{m0sm} / \mathrm{kg}, \mathrm{n}=10)$, 
but a difference in the distribution of osmolality values was observed (Figure 1). Blood osmolalities of controls range from 342 to 369 $\mathrm{m0sm} / \mathrm{kg}$ with the majority of animals (50\%) in the $360-370 \mathrm{m0sm} / \mathrm{kg}$ osmolality range. Blood osmolalities of the exposed animals range from $350-381 \mathrm{m0sm} / \mathrm{kg}$ with $40 \%$ of the animals having osmolalities over those recorded in controls ( $>370 \mathrm{m0sm} / \mathrm{kg}$ ). This tendency of an increased blood osmolality after 6 days of aqueous 4-NP exposure suggests a reduced capacity to tightly regulate ion fluxes in seawater (SW). A hypo-osmoregulatory failure has also been noticed in the gilthead sea-bream (Sparus aurata) injected with $200 \mu \mathrm{g} 4-\mathrm{NP} / \mathrm{g}$ body mass where increased blood osmolalities and a reduction in the renal $\mathrm{Na}^{+} / \mathrm{K}^{+}$-ATPase activity where measured after 10 days. ${ }^{16}$ In the Atlantic salmon Salmo salar, 4-NP has been shown to affect smoltification through decreased branchial $\mathrm{Na}^{+} / \mathrm{K}^{+}-$ATPase activities and $\mathrm{Na}^{+} / \mathrm{K}^{+}$-ATPase $\alpha$-subunit mRNA levels as well as a delayed downstream migration. ${ }^{17}$ In this species, 4-NP seems also to alter hyperosmoregulation. ${ }^{18}$ In the present study, contrary to the Atlantic salmon mentioned above, branchial $\mathrm{Na}^{+} / \mathrm{K}^{+}$-ATPase $\alpha$-subunit mRNA levels are significantly increased in 4-NP exposed fish (Figure 2). This is consistent with a hypoosmoregulatory failure since the sea-bass, contrary to salmonids, has significantly higher branchial $\mathrm{Na}^{+} / \mathrm{K}^{+}$-ATPase $\alpha$-subunit mRNA and $\mathrm{Na}^{+} / \mathrm{K}^{+}$-ATPase activities in fresh water (FW) compared to SW..$^{19,20}$

Osmoregulation is an endocrine-driven function, mediated, in SW-acclimated teleosts, by the growth hormone/insulin-like growth factor I (GH/IGFI) axis and by cortisol that has a dual osmoregulatory function in several teleosts. ${ }^{13}$ In the sea-bass, the pituitary somatolactin mRNA is significantly higher expressed in SW than in FW suggesting an involvement in hypo-osmoregulation however the exact underlining mechanisms are not known. ${ }^{10}$ In order to determine the endocrine pathways by which 4-NP affects hypo-osmoregulation in the sea-bass, we measured the effect of 4-NP on the mRNA expression of two pituitary hormones thought to be involved in the sea-bass hypo-osmoregulation, $\mathrm{GH}$ and $\mathrm{SL}$ (Figure 2).

Pituitary GH is significantly decreased in the exposed animals which might contribute to their hypo-osmoregulatory failure (Figure 2). In the Atlantic salmon, plasma IGF-I levels were decreased in presence of $4-\mathrm{NP}^{7}$ As $\mathrm{GH}$ has been shown to be the major secretagogue of hepatic IGF-I, the IGF-I levels in sea-bass might also be altered. Moreover, Hanson et al. ${ }^{9}$ showed significantly decreased liver and gill growth hormone receptor (GHR2) and putative somatolactin receptor (GHR1) expressions in 4-NP- exposed (at $100 \mu \mathrm{g} / \mathrm{L}$ ) rainbow trouts (Oncorhynchus mykiss). At the gill level and other osmoregulatory organs, 4-NP could also have a direct effect that needs to be investigated in future studies.
Although several physiological functions like reproduction, stress, $\mathrm{Ca}^{2+}$ regulation and acid-balance have been established for the pituitary somatolactin (SL) in teleosts, its involvement in hypo-osmoregulation is still not clear. $^{21}$ SL belongs to the growth hormone/prolactin family and some studies suggest that SL may exerts its effects by the way of the GH/IGF-1 axis and is involved in IGFI regulation.22 Its pituitary expression might also be affected by estrogenic compounds. In the sea-bass however, aqueous 4-NP exposure does not significantly affect SL mRNA expression even if there is a slight tendency of decrease (Figure 2). Further studies are required analyzing circulating plasma levels or investigating the SL putative receptor (GHR1) in order to determine if the SL effects are affected by 4-NP.

Even if the mechanisms through which 4NP affects the GH/IGF-1 axis are still not clear, these data and those in the sea-bass suggest that the alteration of the GH/IGF-1 axis by this compound may be a common phenomenon among teleosts. The slightly higher blood osmolalities combined to decreased $\mathrm{GH}$ mRNA

Table 1. Primer sequences used in this study.

\begin{tabular}{|c|c|c|c|}
\hline Gene & Accession \# & Primer & Nucleotide sequences (from $5^{\prime}$ to $3^{\prime}$ ) \\
\hline Somatolactin & AJ277390 & $\begin{array}{l}\text { SL-F } \\
\text { SL-R }\end{array}$ & $\begin{array}{c}\text { CATCACCAAAGCCTTACCC } \\
\text { GGCACATCATACTGGAATAGGC }\end{array}$ \\
\hline Growth hormone & GQ918491.1 & $\begin{array}{l}\text { GH-F } \\
\text { GH-R }\end{array}$ & $\begin{array}{l}\text { CACAACCTCCACCTGCTCG } \\
\text { GCGTTGTGTCTCGTGCTTGTC }\end{array}$ \\
\hline $\mathrm{Na}^{+} / \mathrm{K}^{+}$ATPase- $\alpha 1$ & AM419034 & $\begin{array}{l}\text { NKA } 1-F \\
\text { NKA } \alpha 1-R\end{array}$ & $\begin{array}{l}\text { AGAGGGATGTTGGCGATGAT } \\
\text { CTGCTGGACGACAACTTTGC }\end{array}$ \\
\hline L13a & DT044539 & $\begin{array}{l}\text { L13a-F } \\
\text { L13a-R }\end{array}$ & $\begin{array}{c}\text { TCTGGAGGACTGTCAGGGGCATGC } \\
\text { AGACGCACAATCTTGAGAGCAG }\end{array}$ \\
\hline
\end{tabular}

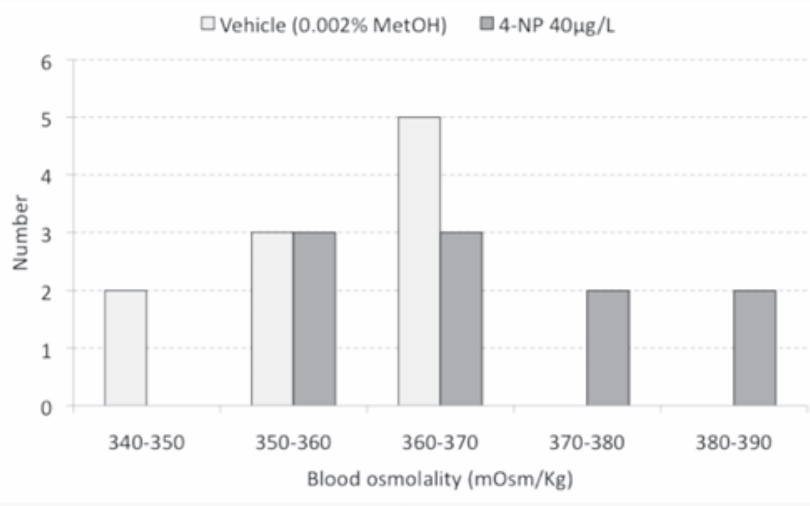

Figure 1. Blood osmolalities in D. labrax exposed to $40 \pm 20 \mu \mathrm{g} / \mathrm{L}$ of 4 -NP or vehicle only $(0.002 \%$ MetOH).

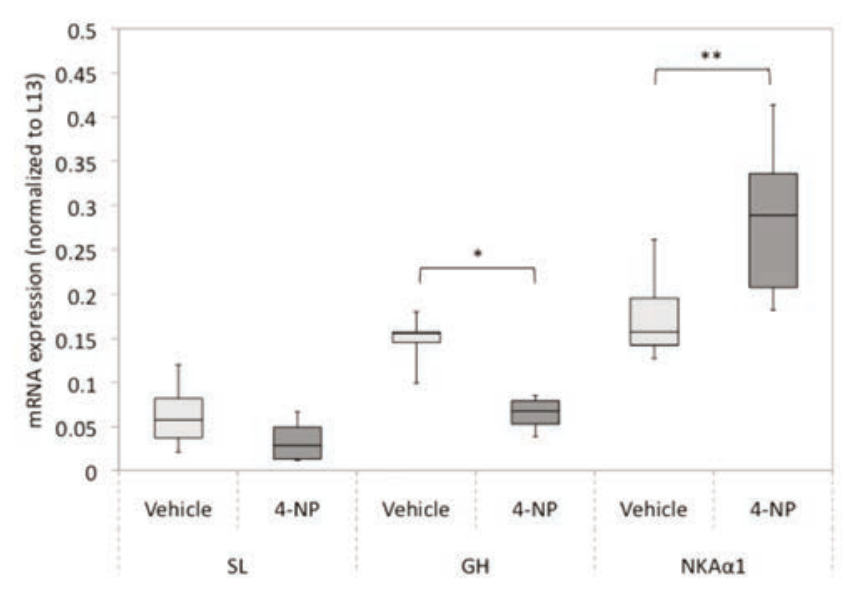

Figure 2. mRNA expression of somatolactin (SL) and growth hormone $(\mathrm{GH})$ in the pituitary gland and $\mathrm{Na}^{+} / \mathrm{K}^{+}$ATPase alpha subunit $(\mathrm{NKA} \alpha 1)$ in the gills of $D$. labrax exposed to $40 \pm 20 \mu \mathrm{g} / \mathrm{L}$ of 4 -NP or vehicle only $(0.002 \% \mathrm{MetOH})$. Data are normalized to the ribosomal RNA L13a and expressed as mean $\pm S D(n=5$ for pituitary gland and $n=10$ for gills). ${ }^{*} \mathrm{P}<0.05 ;{ }^{* *} \mathrm{P}<0.01$ (t-test). 
expression levels show a hypo-osmoregulatory failure in the sea-bass. McCormick et al. ${ }^{7}$ suggested that estrogenic compounds may cause a general shift toward increased capacity for ion uptake and a shift away from ion secretory mechanisms which has to be further investigated in sea-bass. Further research with other estrogenic ligands (natural or synthetic) should help determining the contribution of estrogen signaling pathways towards ionic regulation disruption in fish.

\section{References}

1. Yadetie F, Arukwe A, Goksoyr A, Male R. Induction of hepatic estrogen receptor in juvenile Atlantic salmon in vivo by the environmental estrogen, 4-nonylphenol. Sci Total Environ 1999;233:201-10.

2. Liber K, Knuth ML, Stay FS. An integrated evaluation of the persistence and effects of 4-nonylphenol in an experimental littoral ecosystem. Environ Toxicol Chem 1999;18:357-62.

3. David A, Fenet H, Gomez E. Alkylphenols in marine environments: Distribution monitoring strategies and detection considerations. Mar Pollut Bull 2009;58:953-60.

4. Ackermann G, Schwaiger J, Negele R, Fent K. Effects of long-term nonylphenol exposure on gonadal development and biomarkers of estrogenicity in juvenile rainbow trout Oncorhynchus mykiss. Aquat Toxicol 2002;60:203-21.

5. Jobling $\mathrm{S}$, Tyler C. Endocrine disruption in wild freshwater fish. Pure Appl Chem 2003;75:2219-34.

6. Arsenault JTM, Fairchild WL, MacLatchy DL, Burridge L, Haya K, Brown SB. Effects of water-borne 4-nonylphenol and $17 \beta$ estradiol exposures during parr-smolt transformation on growth and plasma IGFI of Atlantic salmon (Salmo salar L.). Aquat Toxicol 2004;66:255-65.

7. McCormick SD, O'Dea M F, Moeckel AM, Lerner DT, Bjornsson BT. Endocrine disruption of parr-smolt transformation and seawater tolerance of Atlantic salmon by 4 nonylphenol and 17beta-estradiol. Gen Comp Endocrinol 2005;142:280-8.

8. Lerner D, Sheridan M, McCormick S. Estrogenic compounds decrease growth hormone receptor abundance and alter osmoregulation in Atlantic salmon. Gen Comp Endocrinol 2012;179:196-204.

9. Hanson AM, Kittilson JD, Martin LE, Sheridan MA. Environmental estrogens inhibit growth of rainbow trout (Oncorhynchus mykiss) by modulating the growth hormone-insulin-like growth factor system. Gen Comp Endocrinol 2014;196: 130-8.

10. Varsamos S, Xuereb B, Commes T, Flik G, Spanings-Pierrot C. Pituitary hormone mRNA expression in European sea bass Dicentrarchus labrax in seawater and following acclimation to fresh water. J. Endocrinology 2006;191:473-80.

11. Bonga W. The stress response in fish. Physiol Rev 1997;77:591-625.

12. Mancera JM, McCormick SD. Osmoregulatory actions of the GH/IGF axis in non-salmonid teleosts. Comp Biochem Physiol B 1998;121:43-8.

13. McCormick SD. Endocrine control of osmoregulation in Teleost Fish. Am Zool 2001;41:781-94.

14. Tanghe T, Verstraete W. Adsorption of nonylphenol onto granular activated carbon. Water Air Soil Poll 2001;131:61-72.

15. Mitter K, Kotoulas G, Magoulas A, Mulero V, Sepulcre P, Figueras A, et al. Evaluation of candidate reference genes for QPCR during ontogenesis and of immune-rele- vant tissues of European seabass (Dicentrarchus labrax). Comp Biochem Physiol B 2009;153:340-47.

16. Carrera EP, Garcia-Lopez A, Martin del Rio Mdel P, Martinez-Rodriguez G, Sole M, et al. Effects of 17beta-estradiol and 4nonylphenol on osmoregulation and hepatic enzymes in gilthead sea bream (Sparus auratus). Comp Biochem Physiol C 2007; 145:210-7.

17. Madsen SS, Skovbolling S, Nielsen C, Korsgaard B. 17-Beta estradiol and 4nonylphenol delay smolt development and downstream migration in Atlantic salmon, Salmo salar. Aquat Toxicol 2004;68:109-20.

18. Lerner DT, Bjornsson BT, McCormick SD. Aqueous exposure to 4-nonylphenol and 17beta-estradiol increases stress sensitivity and disrupts ion regulatory ability of juvenile Atlantic salmon. Environ Toxicol Chem 2007;26:1433-40.

19. Nebel C, Romestand B, Nègre-Sadargues G, Grousset E, Aujoulat F, Bacal J, et al. Differential freshwater adaptation in juvenile sea-bass Dicentrarchus labrax: Gill and urinary system involvement J Exp Biol 2005;208:3859-71.

20. Bossus M, Charmantier G, Blondeau-Bidet E, Valletta B, Boulo V, Lorin-Nebel C. The ClC-3 chloride channel and osmoregulation in the European Sea Bass, Dicentrarchus labrax. J Comp Physiol B 2013;183:641-62.

21. Ágústsson T, Sundell K, Sakamoto T, Ando M, Björnsson BT. Pituitary gene expression of somatolactin, prolactin, and growth hormone during Atlantic salmon parrsmolt transformation. Aquaculture 2003;222:229-38.

22. Wan G, Chan KM. A study of somatolactin actions by ectopic expression in transgenic zebrafish larvae. J Mol Endocrinol 2010;45:301-15. 